\title{
STORYTELLING AND THE "DIALOGICS OF VARIATION" IN PAOLO MAURENSIG'S LA VARIANTE DI LÜNEBURG
}

To analyze and discuss Paolo Maurensig's first novel, la variante di lüneblug (1993), is to embark upon an ostensibly challenging critical task clue to the scarcity of criticism. As far as I know, the novel has received notewrorthy critical attention by Daniel Mangano, who labels it a "romanzo di formazione" (Mangano 62) by a not too well known author. ${ }^{2}$ Accordingly, the last word has not been said on this novel (and since when has the last word ever been said on any literary text!) which, in many ways presents itself as an innovative literary contribution to the on-going post-traditional concern with literature's self-conscious task in the shaping of postmodern cultural and social identity.

In his article entitled, "Sostiene Tabori: Tematica dell'impegno in La Lariante di lïneburg," Mangano approaches the novel formally and cognitively. illustrating how its narcissistic narrative structure is an allegory of the postmodern condition of heightened egocentrism. Formally speaking, the author isolates the novel's meta-narrative strategies, which according to Mangano depart from the doctrine of mimesis, thereby making La variante di lüneburg not only an exemplary postmodern text mediating on its own "impegno letterario" (literary processes) as an allegory for ethical responsibility towards the other,? but classifying it as "un ottimo romanzo [...] della nuova letteratura italiana." 3

With regards to the novel's assertive and cognitive function, ${ }^{+}$Mangano maintains that the namative devices of the novel, patterned after the stratagems, pauses, and deceitful politics of appearance peculiar to the chess game, allegorize a pessimistic vision of the morld characterized by a dangerous philosophy of non-involvement and by a hyperbolized sense of selfabsorbed individualism which is characteristic of our own contemporaneity. Bearing a comparison between la lariamle di lïmeburg with Antonio Tabucchi's Sostiene Pereira, Mangano writes: 
Tuttavia, il pessimismo che pervade il romanzo di Maurensig e' di un'altra natura. [...] La variante di lïneburg e' stata pubblicata poco prima di Sostiene Pereira [...], un altro romanzo che denuncia i pericoli della pássivita' e del disimpegno di un mondo clella cultura tagliato fuori dalle realta' e dai drammi della Storia. [...] [N]el romanzo di Maurensig come in quello di Tabucchi, il disimpegno deriva dall individualismo del protagonista ed e' soprattutto in questo senso che si manifesta l'urgenza dei due romanzi e la loro compatibilita' con la 'zeitgeist' degli anni novanta." 5

What I propose to do in the following investigation is to fuse Mangano's insightful analysis and commentary of the novel with my own pragmatic conviction that the novel's linguistic narcissism not only allows us to consider the dangers of individualism (Mangano), but moreover asks us to examine how the very act of story-telling in the actual world is itself a praxis of self-preservation and an ideology which introduces in society structures of necessary variance.

This being said, Paolo Maurensig's La variante di lüneburg is a novel that adveritizes and consciously mediates on its own narrative procedures (storytelling) as subversive strategies against a personal rigid ideology. ${ }^{6}$ The novel's elaboration of storytelling as an action of variation and subversion which spearheads an assault on a symbol of rigidity (Dieter Frisch), and as a result reinstates justice in the doxastic world of both narrators, constitutes the novel's social commentary. As such, before the analysis begins, some preliminary and general observations on the cultural and social significance of the narrative form are required.

The ability to narrate stories (whether fictional or factual) which encapsulate and communicate the beliefs, values and aspirations of a society presupposes the need to structure and render intelligible the many human "voices" and points of view making up that society, and in the process of the telling, introduce necessary ideological variation within it. As Jane Yolen suggests in her anthology: "Only humans can create tales that change or structure the world in which they live" (2). Commenting on the nature of stories, she writes: "Stories are powerful. They are a journey and a joining [...] stories are a mystery, giving out clues to open the locked doors of the self" (Yolen 8-9).

In keeping with the pragmatic and experiential notion that stories provide and diffuse new insights into ourselves and the world we inhabit by structuring experience and making it intelligible and more perceptible, ${ }^{7}$ stories introduce ideological diversity in society. For example, in structuring experience, stories offer us alternative paradigms (world perspectives) from 
which to understand and transform the workl. Stories therefore alter the perception of everyday state of affairs by stipulating and clisscminating alternattives to the existing order of things.

Russian Formalists (Shklovskii, 1965, 1966; Tocloror, 1973; 1976; 1990) argue that when in a fictional narrative ordinary language is transformed into a literary speech act, the state of affairs that are stipulated in this literary language undergo "estrangement," or "defamiliarization." In other words, the actual world, or certain variables of the actual world from where the story draws inspiration, and upon which the fictional universe is patterned, is made strange and unfamiliar, and therefore different and new, yjelding new insights. The structuralist reasoning regarding the fictional text's analogous relationship with the extra-textual workd is upheld further by Roberts Scholes when he claims that "fiction offers us not transcriptions of actuality but systematic models which are distinct from reality" (Scholes 6). When this analogous recognition occurs, the literary text encourages its reaclership to rethink critically its walys of cloing things and "forces us into a dramatic awareness of language, refreshes these habitual responses and renders objects more "perceptible" (Terry Eagleton 3). In consequence of this rethinking of our "responses" to social phenomena, we ensure the continuance of society in all its conceptual forms (laws; social values; ethical cluty towards others; etc.). Storytelling therefore is a cultural institution because it keeps a society going by supplying it with new perspectives and concepts which in turn introduce and confirm ideological variation.

An additional concept referring to a structure of social and ideological variation, and indispensable for making us aware of the connection between verbal ant and society, is "heteroglossia." Building on Mikhail Bakhtin's notion of "heteroglossia" as a dialogic phenomenon "multiform in style and variation in speech and voice" (Bakhtin 261), Edwina Taborsky's analysis (The Textual Society) of literature's function in the "social text" posits the idea that all "narrative," and in particular the novel, provides a conceptual framework which is founded on and replicates those structures of icleological variation informing society which are necessary for the continuance of dialogic exchange within a social apparatus. According to Bakhtin, when "social heteroglossia enters the novel, the former becomes subject to an artistic reworking," embodying and expressing "the differentiated socio-ideological position of the author amid the hetereoglossia of his epoch" (Bakhtin 300). Thus, social heteroglossial is an action of social and ideological change. of dialogue and of variance which enters the novel in the form of varied discourses and new styles reflecting "The social and historical voices populat- 
ing language, all its words and all its forms" (Bakhtin 300).

In view of Taborsky's conviction that society can be analyzed "as a text," like a written document that "exists only in usage, only within the actions of being written and read" (Taborsky 198), and that literature functions in this social text as a type of "generative energy" supplying society with its meanings, alternative states of affairs and metaphors, it is interesting to note that her study adopts Bakhtin's notion of the novel as ideological heteroglossia and proposes to use it as a model for social analysis. To paraphrase Taborsky, society itself can be approached and analyzed as a heteroglossic structure, a novel, or as a "dialogic text." She writes: "Society is a dialogic text. It is a continuous interaction and amalgamation of what we may call forces or systems of energy that are differently organized from each other" (Taborsky 161). Therefore, in the same way a novel textualizes different points of view, angles of vision and voices which dialogically struggle for supremacy within a systemized artistic whole, so does the social text embody "heteroglossic cleviation in all its forms, from laughter to criticism, from carnival to rebellion" (Taborsky 169). The novel as an artistic modulation of social heteroglossia is thus fundamental for better understanding the need to embrace icleological tolerance, social change and critical thinking.

Dialectically, Taborsky's "society as text theory" is based on the assumption that both stasis and variation are required for the continued survival of a society. "The social text is made up of two forces," she claims, "the centripetal or the centralizing force of stasis and centrifugal forces of deviation and heteroglossia" (Taborsky 165). Similar to Bakhtin's assertion that the individual author is the carrier of the heterogeneous beliefs of his/her society that will enter his/her narrative, the agent of social heteroglossia for the social text is the individual who, along with other free-thinking individuals, contributes his/her own individuality by articulating idiosyncratic beliefs: "Change in the textual society is achieved via the individual reality level" (Tahorsky 169). Once this action of change occurs, the heteroglossia entering society ensures deviation and ideological tension, challenges stasis, and ultimately means the continued "existence of a society" (Taborskky 191). Thus, a healthy society, like a successful narrative which assembles "a diversity of social speech acts" and multiple stylistic and linguistic properties within a unified artistic structure, is one that ensures its survival by allowing both variance and stasis to co-exist in a dialogic interaction where an ethics of tolerance towards others' opinions underpins human action.

This being said, Paolo Maurensig's first novel. La variante di lüneburg, constitutes a point of cleparture for considering how a novel's gauging of its 
own storytelling properties introckuces an element of variability ("heteroglossia“) in its fictional world, and in the process, wansforms the static and unjust structures defining that world into balanced heteroglossia. The novel thus thematizes the necessity to reinstate a world order defined by justice, dialogue and change, not stasis. Within the context of its metanarrative composition and of the chess-game netaphor (upon which the entire narrative is patterned), 8 the fictional world of the novel constitutes a positive commentary on the ethical duty of permitting variance to enter society, as well as a denouncement of social inertia.

The norel elaborates the story of Tabori, an ex-prisoner of war and master chess-player who, for more than 40 years, has been plagued by insurmountable guilt and by a desire to track down the man who is the caluse of this guilt. He resolves his dilemma by using his adopted son and equally gifted chess-player, Hans Mayer (the second order narrator), as a pawn with whom to track down, and ultimately defeat Dieter Frisch, Tabori's greatest nemesis, the cause of his guilt, and a Nazi war criminal. Not coincidentally, Mayer meets Frisch on the train headed for Vienna and impresses him with his knowledge of chess. Having gained Frisch's confidence and having won his respect, Mayer weaves his tales, and by the end of the telling. Frisch. upon returning to Vienna, is found dead slumped orer a chess board as a result of a fatal gunshot wound to the head.

The novel is comprised of four major narrative sequences (as well as additional minor ones, particularly within the embedded stories themselves) and three digressions the function of which is to offer clues as to the circumstances and reasons surrounding Frisch's death. as well as shed light on the relationship between Frisch and Tabori, the narrator. Furthemore, this metanarrative structure illustrates how the novel gauges itself in an attempt to point to the performative nature of fabulation.

The first narrative sequence (10-34) starts by documenting the place. date and time of the discovery of the body, but does not give any indication as to who committed the crime, or whether it was a suicide or a murcler; The only thing we know for certain is that Frisch was found slumped over a chess board. and that because of allusions made to chess and to the narrator's possible acquaintance with the deceased, the narrator, Tabori, is somehow implicated. Thus, the reader is faced with a mystery plot that presents the crime first, then attempts to take the reader step by step on a joumey of fact-finding revelations and resolutions, thereby reconstructing the events leading up to the crime. It is precisely for this reason that, similar to a chess game the outcome of which is revealed in the moves and stratagems, the 
plot of the novel is patterned after chess. But there is more.

The novel also includes a prologue which constitutes a myse-en-abyme of the entire thematic structure of the narrative. It is essentially a meta-fictional anecdote about the power of storytelling. In the prologue a heterodiegetic narrator (who is probably Tabori) refers to how the chess game was born in bloodshed. "Sembra che l'invenzione degli scacchi sia legato a un fatto di sangue" (9). We are told that the game was introduced for the first time to a sultan by a poor but greedy inventor who, on account of his greed (he wanted in exchange for the chess-game a substantial part of the wheat grown in the Sultan's kingdom), was executed. However, revealing information that official history has kept concealed, the narrator tells an alternative tale: that the sultan also paid a high price for his lack of magnanimity: he went insane: "egli si appassionò al nuovo gioco fino a smarrirne la ragione" (9).

After having narrated his own spin on the legend revealed in the anecdote - whose significance and authorship at this point are vague, - in the first narrative sequence (10-34) the narrator (Tabori) slowly reveals himself to be intimately connected with the past life of the deceased. Before this revelation is made clear, however, the narrator reports the death of Dieter Frisch in the manner of objective reportage, parodying the journalistic manner: "I giornali di oggi riportano la notizia della morte di un uomo, avvenuta in una località non lontaná da Vienna. Ieri, domenica mattina, un certo Dieter Frisch è deceduto per una ferita di arma da fuoco" (10). Then, switching to a more personal point of view, he ambiguously discloses a past connection with the deceased: "Sul momento, ombreggiato com'è dalle falde di un panama che si presume leggerissimo, stento a riconoscere quel volto [...] Mi chiedo se sia possibile che sotto quel nome e quelle sembianze si celi la stessa persona che conoscevo" (10). In the context of Frisch's mysterious death, and the fact that information about the murder and about the narrator's by now certain involvement in it is being given in piece-meal fashion with much apprehension, the switch from journalistic objectivity to personal naration (subjectivity) raises the question as to why the narrator is at this moment engaging in an ambivalent game of revelation and concealment since it is obvious to the reader from his more personal tone that he knows the deceased.

The answer is to be found in the chess-storytelling analogy which the narrator exploits so well. Indeed, a substantial part of the first narrative sequence (from pages 9-15), as with the entire novel, is patterned after a chess game in which we are made to anticipate the nature of Tabori's connection with Frisch from the clues given to us by Tabori's clever strategizing. For instance, the narrator accounts for Frisch's disappearance on Sunday 
and that he was found stumped over a cheap chess board. He quotes ad verbatim the newspaper repont which raises questions as to why such a prominent chess master would choose such a "rag" of a chess board to play his final game, all the while raising suspicion as to his involvement by subsequent comments: Newspaper report: "Nessuno potrà mai spiegarci perchè quella notte il dottor Frisch abbia scelto. dalla sua preziosa e rinovata collezione di scacchiere, un simile cencio" (14-15). Taboris comments: "In queste parole dal gusto vegamente melodramatico è nascosta la verità." What truth? How and why does Tabori know the truth? And how are we to locate it? Not coincidentally, the narrator is partially obscuring his role in the entire affair, not being entirety forthcoming with the disclosure of his implication in, and knowledge of, the crime. opting instead to paraphrase playfully the newspaper reports only to discredit their conclusions and hypotheses:

I titoli danno concordamente un grande risalto alla scomparsa di questa 'eminente figura'. passando però sotto silenzio le circostanze in cui essa è arvenuta. Dietro le pressioni dei familiari, schierati fermamente contro l'ipotesi del suicidio, quasi tutte le testate parlano di 'incidente', 'disgrazia', oppure di morte arvenuta in 'circostanze misteriose' (10).

Epistemologically, this chess patterned narration makes us aware of how knowledge of events or any state of affairs, as stipulated in discourse. is not always so straightforward. Not unlike a clever chess match. knowledge of the world can at times be achieved via pauses, innuendos, false allusions and misleading information. Accordingly, only when we arrive on page nine, after many explicit allusions pointing to the narrator's alleged involvement in, and knowledge of, the reasons behind the crime, do we actually find out that the chess-board upon which Frisch was found dead is Taboris, and that Frisch's cleath was orchestrated by him:

Se le varie ipotesi hanno continuato a oscillare dal suicidio alla disgrazia. sfiorando finanche il delitto. nessuno ha pensato invece alla possibilità di un esecuzione capitale. seppure differita nel tempo e nello spazio. [...] Gli inquirenti non hanno trovato sui pezzi altre impronte se non quelle del defunto: anche se a condurre il gioco, in quel momento, ero io stesso. La scacchiera rinvenuta, infatti, mi apparteneva. e quella posizione di gioco potrei ricostruirla e giocarla a 
occhi chiusi in tutte le sue varianti (15).

As previously mentioned, the narrator's cryptic and ludic attitude towards the information on Frisch is a strategy and pattern upon which the entire novel is based. In this sense, the narrator's playful style of disclosing information underscores the problematic procedures involved in achieving knowledge. This initial display of ludic strategizing is fundamental to the novelistic plot because, unbeknownst to us, it anticipates Frisch's unwitting participation in his own death by a similar chess patterned "coup de narration" that will be orchestrated in the embedded narrative sequence by the second narrator, Tabori's adopted son. Thus, Tabori's quasi reticent attitude is a way of ensuring that the pieces of his plot against Frisch will come together only when he wants. Accordingly, implied in Tabori's strategizing and orchestration of Frisch's murder (even though we still do not know how and why this murder was planned) is a power to control his world in the form of disclosing information when he sees fit.

In the context of this power and control, the significance and authorship of the prologue are revealed. The prologue constitutes a miniature simulacrum by which the narrator's ability to control information and knowledge through the power of discourse is ostended. Departing from the assumption that Tabori is the narrative voice of the prologue, it is possible that he challenges the official legend regarding the downfall of the humble chess inventor in the same manner as he challenges and undermines the newspaper accounts of Frisch's demise by virtue of his privileged position as narratorcreator. Disclosing information when he sees fit (as he does with information pertaining to the circumstances surrounding Frisch's death), and orchestrating the death of Frisch in his own terms, are ways with which to lure us into the narrative game so that we may also become witnesses and players in Frisch's downfall; and these actions symbolize privileges and deeds usually associated with the sovereign position of a narrator who has absolute mastery over the world s/he stipulates, over what he says and how he says it.

In the middle of the first narrative sequence, the reader, having been assured that the narrator orchestrated the death of Frisch, still does not know how Tabori achieved this goal, or the particular reasons behind it. The particulars of the crime in terms of how Frisch met his end at the behest of Tabori will be slowly unveiled when the narrator, having lured us in his narrative trap, temporally digresses to that Friday afternoon and openly admits to have sentenced Frisch to death: "La sentenza è stata pronunciata venerdi 
notte, sul rapido Monaco-Vienna" (15).

The first digression of the novel (16-34), though still part of the first narrative sequence, offers a psychological profile of Frisch; the latter's predilection (no doub a remnant of a Nazi ideology or a static mode of thinking) for distancing himself from the workd of human dialogue and living in a doxastic world of his own fabrication: "Conduceva una vita regolata e tranquilla" (5). A physical projection of this doxastic world is Frisch's home, which is clescribed as a museum rather than a home, and the only people who enter are tourists who marvel at his finely cultivated gardens: "Costruita sul finire del Settecento, non Iontano ctalla capitale, la proprietà era diventata da tempo unattrazione turistica" (11). Frisch's claly activities are to get up in the morning, to have his breakfast, read his newspaper, take a swim and then to close himself up "nel suo studio-biblioteca a occuparsi di scacchi: la sua grande passione" (12). The narrative description of his life is therefore an absolute negation of heteroglossia, a total withdrawal from people, novel icleas, or anything that would amount to a dialogic interaction within the historical process. These descriptions thus juxtapose Frisch's "heterocosm" 9 with the world of variance and progress existing outside his well ordered world.

Appropriately. the narrator's portraiture of Frisch is defined in terms of a man in hiding. a recluse who made himself "una nuova identita, una nuova vita" (18). But the reasons behind Frisch's ner iclentity and life are not given. thereby raising suspicion as to some past deed that ought to remain hidden. He describes Frisch's passion for chess in terms bordering on obsession and symbolic of the rigidity defining his life: "Frisch si riteneva un purista del gioco, aborriva tutto ciò che non gli sembrava logico, lineare, o per lo meno riconducibile a una qualche teoria gia esistente" (25). And the narrator. himself a self-prochaimed expert at chess, alludes to how Frisch's chess obsession lead to his eventual downfall: "e tuttavia a perclerlo è stata proprio la sua irriducibile passione per gli scacchi" (16) (18). These are but a few in a series of partial revelations and allusions which point not only to chess as the instrument of Frisch's death, but which also imply some connection between Frisch, Tabori and chess. In fact, the narrator informs us about an inciclent in which Frisch, criticizing in his chess journal the use of an unorthodox chess variation which quickly determines the game's outcome by introducing an element of unprectictability in the game. demonstrated his aversion towards any violation of his own brand of the aesthetic status quo: "Questa variante gli era subito apparsa come un affronto ai suoi personali canoni di orctine estetico. Vi avera dedicato uno studio ponderoso che si era 
protratto per parecchi numeri. L'aveva intitolato La variante di Lüneburg" (26). What we do not know at this moment, but will only be privy to towards the end of the novel, is that Tabori introduced the chess variation through Mayer so as to ensnare Frisch's interest, find out his whereabouts, track him down via his son, Hans Mayer, and deliver the final assault.

As the first narrative sequence accounts for Frisch's habits and whereabouts two days before his death (Friday afternoon), Tabori-narrator suddenly focuses on Hans Mayer, the second order narrator, who introduces himself to Frisch on the Vienna express train headed for Munich. Tabori thus disappears from the central fabula, and the train therefore becomes the locus for the setting of Mayer's trap, which will be enacted in the second narrative.

Thus is introduced the second narrative sequence (34-68), as Hans Mayer attempts to gain the trust required to lead Dieter Frisch where he wants him to go: to listen to a story, and to recognize himself as Tabori's Nazi tomentor. In fact, the teleology of the tale is made explicit by reference to its function as an attention getting strategy: "Il silenzio dei due uomini e l'attenzione fissa, apertamente incuriosita, di Frisch indussero Mayer a iniziare il suo racconto" (34).

The rhetorical devices Hans Mayor exploits in his tale are hyperbole and war metaphors expressed with a heightened sense of intellect; rhetorical strategies and tropes that will win the trust of a man whose present life stands for obsessive behavior and intellectual arrogance, and whose past recalls unparalleled murder and war. Mayer states: La mia passione si rivelò dunque immediata e implacabile. Per un certo tempo, mi bastò muovere quei pezzi sulle case della scacchiera, sentirne la consistenza, o anche solo guardarli" (38). Making hyperbolic remarks such as not being able to sleep or think because of the chess obsession, Mayer, certain of Frisch's attention due to the latter's equal obsession for chess, informs him that his entire existence was limited to chess-playing, where no time was allotted to other pursuits. Flaunting his knowledge of the great chess-players of the past, Mayer says: "Come ben sapete, Alechin sosteneva che gli scacchi sono unarte, mentre Cápablancá li vedeva come pure tecnica; per Lasker, invece, gli scacchi significavano lotta" (39). Having gained Frisch's trust, Mayer introduces Tabori in his tale, thereby inserting an additional narrative layer within his own story. He talks of their mentor-student relationship and about the tedious lessons of chess. He also speaks of the ethical lessons he learned while under Tabori's tutelage.

One such lesson requires mention for the reason that it illustrates the con- 
nection between chess, fabulation and life, constituting yet another narrative frame embedded within Mayer's story which is meant to make Frisch recognize himself in the narrator's tale. Mayer tells of a time when Tabori gave him a newspaper article about the accidental death and injury of 14 schoolchildren. On the back of the anticle Tabori wrote: "Accioche u rifletta meglio" (62). And in smaller print was written: "E se lá causa cli tutto questo fosse stata la tua disattenzione?" (63).

The content of the embedded story of the fourteen school children is Taboris way of instilling in the young Hans Mayer the same sense of ethical responsibility and respect towards the game of chess as he should have towards human life. By implication, however, this ethical invective alludes to Frisch, whose past life was anything but ethical. Therefore. Mayer's decision to narrate this incident to Frisch reflects a strategic move on his part meant to trigger Frisch's recognition of his own evil past. As we will be privy to in the final narrative sequence. the original author of the subjunctive sentence - Acciochè tu rifletta meglio - was Frisch, who churing the war wrote it on the back of photographs of murdered victims for whose deaths Tabori was unwittingly responsible.

Halfway into his story, Mayer stops narrating (68). and the primary narrator, Tabori, intervenes and introduces the novel's second analepsis, or narrative digression. The function of the second digression is to comment on, and assess, the effects of Mayer's tale on Frisch, as well as to underscore the chess-storytelling parallel. Tabori, assuming his previous omnipresence. remarks that Frisch asked Mayer to continue his story, a possible indication of his being suspicious, as rell an indication that Mayer's plan is working: "Un gesto che clenotava curiosità, e forse anche una lieve apprensione" (69). At the behest of Frisch's signal to continue his story - "continui, la prego" (69), the heterocliegetic narrator (Tabori) intervenes in the former's direct discourse and, as if making a remark about a chess move. comments upon how the recommencement of Mayer's tale is similar to a chess move: "Era la mossa che Mayer aspettava: ora si sentiva perfettamente a suo agio. Gli succedeva la stessa cosa quando giocava a scacchi" (69). In view of how the novel has thus far underscored the chess-storytelling parallel in both Tabori's and Mayer's clever narrative strategizing, it is not surprising that Mayer's own storytelling maneuvers replicate the strategizing involved in chess.

At the level of content, Mayer's embeded tale about the 14 schoolchildren signifies the ethical responsibility one should assume towards others. This is clear enough. At the level of form. however, the story-within-al-story framenork, as is revealed through Mayer's tale, through his embeclded frame 
of the 14 school children and through Tabori's digression, underscores how the act of storytelling is meant to deconstruct Frisch's doxastic world by disclosing past scenarios meant to trigger his memory. In light of how Mayer's embedded story is meant to trigger memory and destroy Frisch's personal heterocosm, the novel consciously foregrounds its narrative structures of subversion and variance. As a matter of fact, it is Tabori-narrator-orchestrator who fabricates and manipulates in absentia the meeting between Frisch and Mayer with the authority entrusted upon him as an omniscient narrator. A similar manipulation is evident in the prologue of the novel where we have two contradictory versions (in one the potentate is sane, while in another the potentate is insane) about one state of affair that are reported by the narrator; yet which ever version is true, lies in the privy of Tabori, the only vox autoritatis in the text. Thus it is Tabori's discourse that challenges the official cliscourse of the legend, and therefore reveals the alternative morality anecdote of how the potentate paid a high price for his lack of trust. Equally relevant, it is Tabori who plays with his readers in the Frisch murder case by disclosing and concurrently keeping information from them, thereby raising clramatic irony by flaunting his superior knowledge to the inquisitive reader and creating a fictional world based on parallels between chess, life and storytelling. Moreover, it is via Mayer's storytelling abilities that we are offered the ethical content of his tale. And more importantly, it is through storytelling that we will eventually witness Frisch's ironic clemise.

Viewed from this perspective, the real content of the novel is the formal gauging of its own means of narrative production which organize the fictional world according to rhetorical (chess-storytelling analogy; digressions) and stylistic parameters (pauses; interjections; innuendos; quasi resolutions). Therefore, it is not so much what the novel signifies that is important (Frisch the recluse; Tabori's revenge; the parallel chess-storytelling; the ethics of responsible action; the exploitative nature of life; etc.), as how it stipulates it through metanarative techniques which critically draw our attention to how narrative acts actually alter our perception of the world by disclosing themselves as strategies of world construction: It is by means of language and its storytelling agent, narrative, that Mayer constructs a possible world that will not include Frisch, symbol of tyranny and stasis.

The third narrative sequence (70-84) constitutes Mayer's reprisal of his tale, and as mentioned earlier, signifies a most significant strategic move in his narrative game. The characteristics of this part of his tale differ from the predigression one insofar as this one displays a more philosophical-speculative position, as well als revealing itself to be more conscious of its own strate- 
gizing. Speaking about his training from his master Tabori, Mayer assures Frisch that the world of chess constitutes another dimension in which any sense of sell and the actual world is annihilated for the sake of the game:
L'angusta cella all'ultimo piano della Pension Fischer diventò il mio santuario e lá mia prigione. Ben poco restò del mondo circostante, che a poco a poco perse consistenzal: e se cera ancora un corpo con le mie sembianze che frequentava le aule di una scuola, che ogni tanto andava a far visita a mia nonna, che mangiava, dormiva e percorreva gli itinerari abituali, io ero sempre lì rinchiuso in quello spazio, alle prese con me stesso (76).

Heading towards his conclusion, Mayer informs Frisch that he lost all contact with Tabori, and as a consequence, has not played another game of chess. Then Mayer invokes his knowledge and use of the chess variation (passed down to him by Tabori) which Frisch himself is reported to have severely criticized in his purist chess journal:

C'era una sola condizione inderogabile in questo nostro sodalizio. Tabori volle a tutti i costi che al 'gambetto di donna' clel bianco io adottassi sempre una certa variante che mi aveva insegnato [...]. Questa variante implica un sacrificio di cavallo, dopodichè si precipiti nel caos. Tabori ci teneva in modo tutto particolare. Spesso mi clicera che quello era il suo contributo alla storia degli scacchi (80).

Dramatic irony in the above passage is generated by what Mayer knows about Frisch's knowledge of the chess variation in contradistinction to what Frisch does not know: mainly that Mayer's tale is meant to incrimminate Frisch and expose him as a Nazi war crimminal in hiding who shares a terrible past with Tabori. The philosophical and strategic aspects of Mayer's speech complement each other insofar as Frisch is made to respect Mayer's obsessive knowledge with chess, and as a consequence, allows himself to be drawn into Mayer's explanation of the chess variation; the clue that will trigger Frisch's memory regarding his past with Tabori and demonstrate that Mayer's storytelling signifies him as the hidden antagonist. Accordingly. Mayer's intentional disclosure of his playing the chess variation on the international chess circuit, and that his teacher was Tabori, recalls Taboris allusion to the variation defense in the first narratives sequence: "e quella posizione di gioco potrei ricostruirla e giocarla a occhi chiusi in tutte le sue varianti. Questa difesa, che Frisch aveva tentato inutilmente di demolire era 
l'unica cosa che ci legasse a un sogno infame del passato" (15). Therefore, Mayer's reference to his playing the variation reveals to the reader information about Tabori's plot: If the variation is that which binds Tabori and Frisch to an "infame passato," and if Mayer was taught and played this same chess variation, which Tabori claims is that which lead him to Frisch ("di risalire fino alla persona"), then Tabori used Mayer as a pawn to play the variation internationally. Knowing full well that Frisch was editor of a chess journal and would jump at the chance to discredit the variation publicly, Tabori tracked Frisch clown. The reader is therefore responsible for reconstructing the events which lead to Frisch's demise. The burden of meaning-making has shifted from the text to the reader. The parallels between the act of storytelling and chess are again indisputable: The way we and Frisch are given information, and the way we are made to piece it together by conjecture and logical hypothesizing is analogous to the way one either wins at chess, or to the way a reader reconstructs, and therefore renders intelligible, the disconnected and seemingly unelated narrative events informing a story's fabula. In the third digression (only a paragraph's length) Tabori interjects, and as in the preceding digression, authoritatively comments on the reaction and the exchange that ensue between Frisch and Mayer: "Qui Mayer tacque: voleva vedere infatti quale effetto avesse avuto il suo racconto sui suoi due interlocutori" (84). Apart from the obvious reason that an interuption of Hans Mayer's fabula raises dramatic tension because as readers we are anxious to witness Frisch's reactions as to his role as antagonist in Mayer's tale, Tabori's digression serves a dual purpose, one functional the other demonstrative.

On the one hand, the digression constitutes an attention-getting device in consciously sizing up the tale's ("racconto") functional-performative role: What is Frisch's reaction to the tale itself? What will Frisch tell Mayer? How will he admit his implicattion in what Mayer narrated? How will Dieter Frisch be lead to his death by a simple act of fabulation? On the other, the digression documents a step by step adversarial chess-type relationship between Mayer, who is now a predator, and Frisch, who is now a victim. Indeed, Tabori's comments depict this scene as a chess game which requires that both adversatries be involved in absolute concentration and solitude: "Il treno riprese la suá corsa, e nessun altro entrò nel loro scompartimento. Hans accostò la portá che Baum aveva lasciato aperta, e tornò a sedersi, questa volta pero sulla poltrona lasciata libera da Baum stesso, mettendosi così di fronte allaltro cone a un avversario, con il fare di chi si appresti a concludere rapidamente la partita" (85). Frisch's reaction to this seating position 
is clescribed as follows: "A frisch non eral sfuggita la manorra. Areva aruto quasi un moto di sorpresa. e per superare il disappunto guardo l'orologio. "Siamo in perfetto orario" disse. A mezzanotte saremo a Vienna" (85). The narrator's words, "manovra" and "moto di sorpresa," again function as attention getters since they explicitly allude to moves associated with chess games, thus creating an adversarial type amosphere. Also, Frisch s clever pretense of looking at his watch while analyzing Malyer's move illustrates the clever improvisation and intellectual acumen involved in chess-playing. As Daniel Mangano observes, the chess symbolism in this novel is multifaceted. covering a variety of themes, one of which is intellectual prowess: "Gli scacchi come elemento di violenza e di cupidagine clunque, ma anche di follia. il gioco considerato nel suo duplice aspetto cli fonte di piacere intellettualle e di strumento di tortura e di morte" (Daniel Mangano 53).

Thus, as the tension develops, both characters are depicted in the context of their mutual antagonism where each, like expert chess players, anticipates the other's move in an attempt to thwart one another. Except in this game pawns are replaced by words, moves by clever rhetorical skills, and the board, by life itself, symbolically stipulated by the moving train. In this sense, the Frisch-Mayer struggle on the train is symbolically recast within a narrative apparatus where there are fundamentally two games being played: a storytelling game patterned upon the strategizing and improvising involved in the chess game, and an actual chess game reflecting in its tum the properties of narative nuance. In other words, it is by means of an autobiographical anecdote that Mayer is able to maneuver Frisch to listen to him in the first place. And it will be the tale that will ultimately force a confession from Frisch, and change the lives of both Mayer and Tabori. Each move therefore. while paralleling chess maneuvers, also involves rhetorical moves. an intellectual strategy and a narative one where each adrersary attempts to outsmart the other by the use of clever allusions and word-play. For instance. feigning ignorance and contemplating his next move, Frisch finally makes an attempt to acknowledge that it was he who wrote against the lüneburg chess variation, and that he recalls Mayer as the player of that variation. The narator illustrates this scene through direct cliscourse so as to underscore directly Frisch's clever strategy of pauses which deflect attention and point instead to a casual attitude: "Frisch, che per un po" era sembrato chiedersi a chi clei clue spettasse la mossa, pronunciò invece il nome di Mayer più volte e sottoroce, come se gli potesse evocare qualcosa: -Mayer...Mayer...Hans Mayer... Mi sembra di ricordare un certo Mayer che ha fatto parlare di sé l’anno scorso ad Amburgo, é poi, se non shaglio, a 
Hastings" (86). Mayer, on the other hand, says nothing to this, a narrative pause is his weapon. He listens rather, as Frisch flaunts his chess playing abilities and criticizes the variation. "Un carattere debole, il suo..." (86), he says to Mayer; a disparaging remark against the latter's using of a variation that is, in Frisch's opinion, devoid of rational thinking.

Towards the end of the third narrative sequence, Mayer makes his last move in the hopes of making Frisch realize that this entire storytelling strategy is a prelude to something else. Mayer offers to give Frisch Tabori's chess board of pain (which sends an electric shock to the player who makes irresponsible moves) in exchange for Frisch's willingness to allow Mayer to finish his tale: "Ciò che le chiedo in cambio è [...] di ascoltare sino in fondo la mia storia" (88). Tabori-narrator, however, again interjects in their match and comments upon Frisch's obvious awareness that he has been duped: "Frisch si sentiva irritato per essersi prestato troppo ingenuamente al gioco" (88). And then, approving of Mayer's strategizing with words reminiscent of chess, the narrator says: "Posso dirlo con sicurezza, nello sguardo di Hans Mayer traspariva lintima soddisfazione dello scachista che veda realizzarsi sulla scahhiera, mossa clopo mossa, tutto ciò che aveva previsto, e pensi: 'Ecco il finale'” (89). Significantly, Tabori's comments, as with all his digressions, not only size up the Frisch-Mayer struggle by offering the "players" respective reactions, but moreover impose a measurable degree of the chess structure upon the entire novel.

Tabori's digressive interjections thus serve as the structural principle that constantly reminds us of the chess-storytelling analogy and of the way his entire fictional world is patterned after it: "Da quel momento in poi tutto era dunque afficlato alla pura tecnica. Non c'era bisogno di improvvisazione, di genialità, ma semplicemente di tecnicá" Come un musicista, prima di rispondere misurò con il respiro una pausa coronata" (89). Tabori's musical analogy is a telling sign of how the formal structures of the novel (the choice of words; the story-within-a-story structure that underscores the power of narrative; the chess-story analogies) consciously underscore the chess-art parallel. Within the realm of art. Tabori's musical analogy therefore implies a similarity between chess and storytelling. In fact, references to the chess-art analogy abound: "Gli scacchi, come le arti, sembrano darci la possibilità di sopravvivere alla morte fisica, di avere fama eterna"(87). Just as a clever story teller weaves his tale and captures the reader with his/her themes (content) and use of metaphors, but also relies on his/her ability to tell a story well by using effective intonation, pauses, style and manner of speaking (formal technique), so does Mayer capture and ultimately thwart Frisch by 
using his own thetorical latents.

Mayer's move is made in the closing of the third digression. He discloses to his adversaty the fact that Tabori used him as a pawn to track down a man with whom he shared an evil past and a chess-game. Frisch, obviously aware that he is that man says: "Suppongo di essere jo quest uomo"(91).

The fourth and final narrative sequence, with its own embedded text, introduces Tabori as a homodiegetic narrator involved in the story he narrates. With his inclusion we have a revelation which recalls and resolves all the cryptic allusions made in the previous narrative sequences and digressions. Let us recapitulate: The first narative sequence establishes the crime and points to Tabori as implicated in the crime by a chess board. The second narrative sequence, interrupted by two digressions, introduces Mayer's lale as a strategy with which to gain trust and ultimately achieve a confession. The content of the tale is also meant to communicate an ethical lesson of responsible action, while its formal aspects reinforce the chess-storytelling analogy. The third narrative sequence displays a more decisive attempt at strategizing and bringing about Frisch's eventual confession by way of the revelation of Mayer's playing the notorious lüneburg chess variation. Thus, by the time we arrive at end of the third narrative sequence, this is what we know: That Hans Mayer is Tabori's adopted son, and that the latter is somehow involved in Frisch's death (first narative sequence); that Tabori sent Mayer to track down Frisch (second narrative sequence); that Frisch and Tabori share a common past, and that Frisch's death on a chess board is somehow related to Tabori (third narrative sequence). What remains to be revealed are the reasons behind Frisch's death, the nature of the relationship between Frisch and Tabori, and the significance of chess in the entire affair. The fourth narrative sequence narrated by Tabori supplies the answers. Tabori narrates how he was made to play chess for the lives of inmates in the Bergen-Belsen concentration camps during the second World war by Frisch, who was then commander of the camp. They had met years before as children at a chess tournament during the implementation of the Nazi racial laws. Within this context, Tabori, being Jewish, did not stand a chance at winning, especially when the opponent was Frisch, a German. Thus. Tabori was ridiculed, and when in fact won matches, was second-guessed by partial judges who farored German players, and gave them the winning score. This notwithstanding. Tabori won many toumaments, and Frisch naturally held a grudge. When Tabori's family was imprisoned (and subsequently killed in the camps). Tabori was sared by Frisch because the latter wanted to exact revenge. The revenge was cunning and cruel. Frisch lead 
Tabori believe that losing to him at chess was a way of winning favor and saving his own life. But unbeknownst to Tabori, every game that he lost was a death sentence for other inmates. So, Tabori had to win games for the lives of inmates. It was in the Bergen-Belsen concentration camp that Tabori first used the lüneburg variation as a necessary strategy of subversion against Frisch's cruelty.

Tabori's embedded story, contained within the fourth narrative sequence, also details the inhumane conditions of the camps which destroyed the morale of the inmates. In this context where justice, dignity and human worth are meaningless concepts, Tabori learnt the value of being responsible for his actions. But he also left the concentration camp with insurmountable guilt for not only having survived, but for having unwittingly been the cause of many deaths. He was made to wager the lives of prisoners on a chess game which. for Frisch ras just that, a game, but for Tabori, was cruel life playing a cruel game. It is at this point in the novel where Mayer's embedded tale acquires its full moral and ethical significance - its reference to an ethics of responsible action and its function as a subversive strategy of heteroglossia directed against an immoral and one-dimensional ideology. Mayer's story was meant to bring about the creation of a world or state of affair the aim of which was to prepare Frisch for his eventual retribution by triggering his memory as to his past unethical actions towards human kind. In other words. what history failed to provide, mainly justice, fabulation will minister.

As a functional extension of Tabori's tale, Hans Mayer's own storytelling role in the previous narrative sequences on the train was to establish a state of affairs based on a "natural compensation." The nature of Tabori's brand of "natural compensation" therefore was to have Frisch confront his past through a story, and in consequence of this, to lose his life on a chess match as the ultimate irony and retribution for having clone the same to others.

Il fatto che, interrotta la linea del sangue, sia

Hans, mio figlio adottivo in extremis, a portare a termine questo compito, mi solleva da un accresciuto autosospetto di malfede, di desiderio di vendetta personale, ridandomi l'illusione che si sia ristabilita non dico la giustizia, ma almeno una sorta di equilibrio di compensazione naturale (92).

When reading this part of the novel we must remember that Tabori's story- 
telling is but an echo of the same story being told off scene on the train: "Lasciamo che il treno prosegua la sua corsa" (92). Instead of Mayer, Tabori himself will deliver his own story while informing us that the same story is being told to Frisch on the train: "Meno di un'ora li separa dál Vienna, il tempo necessario perche Hans conduca a termine il suo finale di partita raccontando alla persona che si cela sotto il nome di Frisch la mia storia [emphasis author's] (92). This technique raises the question as to why not simply have Mayer narrate 'Tabori's tale in third person narrative? After all. that is why Tabori sent Mayer to Frisch, for the former to tell him a story and make him achieve retribution for the evil he had caused Tabori and others. What is the efficacy of Tabori's intervention?

Significantly, this peculiar narrative technique by which the same story being narrated within the fourth sequence by Tabori is also being narrated "off scene" by Mayer emphasizes the novel's gauging of its own storytelling powers: The way storytelling constitutes an action of variability and dissolves Frisch's existing modus vivendi or actual world. In choosing to narrate his story in his own voice and from his own perspective, while acknowledging that the same story is being narrated on the train as an illustration of Mayer's last narrative maneuver to unmask Frisch's past ("raccontando alla persona che si cela sotto il nome di Frisch la mia storia"), Tabori's/Mayer's paralleled storytelling actions self-consciously gauge themselves as strategic acts which reinforce the notion that stories, and the act of narrating them, are performative devices that bring about changes in the rorld: in this sense, Tabori's tale dismantles Frisch's fictional heterocosm by instigating his death, by underminig the static rules of his aesthetically well- ordered life.

Moreover, in destroying Frisch's rigid world, Tabori creates a new world order: A livable and just world without Frisch, a world where, on a small scale at least, justice has been reinstated, and a Nazi war criminal in hiding has reckoned with his sins in the most ironic of ways. Thus, from an ontological perspective, Tabori's story of personal triumph actually brings into existence a world informed by a dialogics of variation; a world grounded in the necessary tension between contripetal and centrifugal ideologies which, in consequence of this dialectic, introduce deviation into a static one-dimensional world. In light of the heteroglossic notion that "change in the textual society is achieved via the individual" (Taborsky I69), both Tabori's and Mayer's storytelling are subversive acts, actions of an idiosyncratic rebellious heteroglossia which alter the well ordered fictional world of Frisch, and introduce in the actual world an element of variance, change and rebellion, and with it, an ideology of reaction. In point of fact, when reconstructing his 
chess matches with his father as a young man, Tabori makes a point, as Mayer did in his tale, of underscoring his predilection for variance and disruption and for changing the rules of the game: "Potevo permettermi di sovvertire apparentamente le regole [...] e di trascinare in tal modo le partite nelle complicazioni più bizzare" (101). As far as the fictional world of this novel goes, both Mayer's and Taboris tales - which are modulated into actions of variance - subvert Frisch's life; the life of a solitary figure who was living in the fiction of an alias, and who was a symbol of a time when ideological differences were not tolerated, and when conformity was the rule of the game.

At the end of his tale. Tabori expresses the idea that his victory over Frisch in chess during those days at Bergen-Belsen was meaningless: "pur avendo vinto sulla scacchiera, sono stato in realta io il vero sconfitto, perchè sin dal primo momento ero stato complice di un disegno rivoltante. Il semplice fatto di essere rimasto in vita, testimone impunito dei loro assassini, mi accomunava ad essi" (157). Similarly, in light of Tabori's initial remarks in the first narrative sequence - which are verbalized after Frisch's death - his victory over his nemesis in the present is also meaningless: "Per me non credo ci sia più scampo, poco mi resta ancora da vivere e la morte, temo, non sarà una liberazione" (18). But, as the reference to "compensazione naturale" seems to imply, attempts to stamp out voices of tyranny and fascism and reinstate an ideology of ethical responsibility in human society must remain ideals worth pursuing.

The novel's quasi pessimistic ending constitutes its commentary on state of the world. in whatever epoch. Life needs variation as much as it needs stasis, for without the latter, we cannot attain the lofty goals of the former. Life needs the individual who, together with other "voices," may ideally make a difference in the state of affairs of the world. Curiously, without the tyrannical voices and the static political systems that rob our basic claims to freedom, the attainment of ethical postures to uphold freedom would be impossible. If indeed "heteroglossia is what makes life worth living" (Taborsky 192), then Maurensig's novel mediates on the unavoidable agonism, tensions, as well as benefits. characterizing all human history. The references to chess-playing and how the game parallels life's stratagems and improvisations imply as much. Moreover, Frisch's disparaging remarks about the lüneburg defense variation in his journal, and Tabori's endorsement of it, reflect and illustrate the perpetual ideological struggles underpinning the modern world today. There is within this ideological tension, however, a solution. 
Indeed, the novel's self-conscious gauging of its subversive storytelling strategies reflects a balance and a solution to this existential agonism by supplying the necessary structures of social change. Thus, the chess-game-type storytelling, as it is worked out in the novel's meta-narrative structure, is a metaphor for life, which requires the necessary ideological variations and actions of heteroglossia in order for it to perpetuate itself. As far as Maurensig's fictional world is concerned, Frisch's murder, even though unjust from the point of view of the law (since it implies a taking of legal matters in one's own hands), ultimately signifies that storytelling has served its heteroglossic purpose by eclipsing a symbol of tyranny, thereby making a statement about the need to rebel against static state of affairs which rob us of our humanity and turn us into victims and predators.

Contrary to this line of positive reasoning, despite the novel's endorsement of narrative heteroglossia as a strategy of ideological change and ethical duties towards humankind, Tabori's actions in the Bergen-Belsen concentration camp seem to contradict the dialogics of variation. His antagonistic involvement with Frisch during the war clearly demonstrates how he became an unwilling assassin, caught up in a static system of conformity and non-action. His individual roice and his heteroglossic principles were eclipsed by a discourse of tyranny which hypostatized indifference towards inclividual uniqueness. In fact, he mentions that his actions differed slightly from his Nazi tormentors - "mi accomunava ad essi". What his son's and his own narrative coup d'etat did 40 years after the fact was simply to reinstate a sense of delayed justice.

In the light of the Bakhtinian interpretation of the novel "as a diversity of social speech types and a diversity of individual voices, artistically organized," and within the context of Taborsky's interpretation of society as "an infrastructure of differentiation" (190) made up of "multiple voices and multiple perspectives," this novel warns against the dangers of ideological rigidity. Paradoxically, if this novel has anything to say about the state of our post-traditional world, it is that, despite our drive to introduce heteroglossic deviation in a global village which "is rejecting variation or heteroglossia and is actually preventing any and all actions of chalogue" (Taborsky 186). We can nonetheless become victims of the same rigid individualism and ideology we seek to abolish. In other words, within our present context of prevailing ontological possibilities (alternative ways of being, thinking acting) which struggle to survive in the lace of ideological rigidity brought about by global conformity, we also may become, as Tabori and Frisch, victims of our own individualism and unwitting assassins of the good in human nature. 
Against such a negative view, however, in light of the novel's portrayal of storytelling as a self-preserving device that endorses a dialogics of variation, Maurensig's novel foregrounds the ethical, self-preserving and self-legitimating possibilities of literary (artistic) creation.

\section{Unicersity of Toronto.}

\section{NOTES}

1. In the introduction to his article, Mangano writes: "Di Paolo Maurensig, si sanno pochissime cose."'Sostiene Tabori": Tematica dell'impegno in La variante di luneburg." Narrativa 12 (Sept. 1997): 51-65.

2. According to Mangano, literary devices and chess moves coalesce in this novel of tricks, stratagems and word-play. The omniscient narator (Tabori) with his pauses, constant narrative regressions and ambiguously delivered information, and the reader who attempts to reconstruct the story by negotiating the narrator's evasive discourse are both involved in a game whose final outcome is the denouncement of passivity in the face of crimes against humanity: "Má per questo, il giocatore deve sviluppare un'etica della responsabilita' che cominci col rịconoscere che la prima forma d'impegno, quella piu' fondamentale, consiste nel combattere i demoni covati dentro di noi. La nostra societa' postmoderna e' sempre piu' quella clell'apparenza" (63).

3. Mangano 65

4. By the cognitive process known as "analogous configuration" (Barbara Foley 1986), a fictional text makes statements about the actual world by presenting itself as a model which recongfigures aspects of actual esperience, particular or universal, within its own fictional domain, thereby making the fictional world sufficiently recognizable to the reader. At the same time, and working in opposite directions, a fictional text also alters the actual world model and makes it strange or new. In this sense, as Robert Scholes argues, fiction is "distinct from reality," thereby challenging us to perceive new relationships and state of affairs that would otherwise be albsent from cognition without fictional intervention. See also Robert Scholes 1975.

5. Mangano 62.

6. By a narrative subversion of a "personal rigid ideology" I essentially refer to the novel's thematizing of how the two protagonist-narrators (Tabori-Hans Mayer) exploit storytelling in order to dismantle the life of a man whose experiences in the world symbolize corruption, hypocrisy. rigidity and stasis. Since the denouncement of a rigid ideology, either individual or collective, implies a revolutionary attitude and a politics of confrontation (a reaction against a prescribed order of things), the novel, according to Daniel Mangano, "denuncia i pericoli della passivita" e del disimpegno" (62).

7. In his Structmual Fabulation. An Essay' on Fiction of the Future, Robert Scholes argues for the cognitive and sublininal function of stories. Fictions, he maintains, "take our worst lears and tame them by organizing them in a form charged with meaning and value" (5). La varante di lumeburg thematizes this multiple function in its meta-fictional narrative structure by illustrating how the novel can be used as a "systematic model" offering society resolutions to actual dilemmas, thereby allowing us to experience viacariously life's seemingly contradictory state of affairs.

8. "Tutta la struttura narratologica del romanzo è basata sul ritmo del gioco degli scac- 
chi. mosisa dopo mossa" (Mangano 64).

"As proposed by Linda Hutcheon in her study of meta-narrative fiction, the term "heterocosm" signifies an atutonomous fictional world created within language. Essentially; it is an aesthetic topos created within a metat-narrative context which underscores how human agents stipulate their own world versions through verbal conceptualization. Frisch's workd is analogous to a "heterocosm" insolar as his existence is defined by the discourse of chess and is validated within a static ontology where no influences from the outside wortd are permitted to enter. For a complete explication of the term. I refer the reader to Linda Hutcheon (231-266)

\section{WORKS CITED}

Bakhtin, M.M. The Dialogic Imagination. Ecl. Michael Holquist. Trans. Cary Emerson and Michael Holquist. Austin: Lniversity of Texas. 1981.

Eagleton, Terry. Literary Theory: An Introduction. Minneapolis: 2nd edition, University of Minnesota Press, 1996.

Foley, Barbara. Telling the Truth. The Theory and Practice of Documentary Fiction. Ithaca and London: Cornell LP, 1986.

Hutcheon. Linda. "Narcissistic Narrative: The Paradoxical Status of Self-Conscious Fiction." Diss.. Lniversity of Toronto. 1975.

Mangano. Daniel. "Sostiene Tabori": Tematica dell'impegno in La lariante di lüneblirg." Narrativa 12

(Sept. 1997): 51-65.

Maurensig. Paolo. La l'ariante di lünebarg. Milano: Adelphi. 1993.

Scholes. Robert. Structural Fabulation. An Essay on Fiction of the Future. Notre Dame \& London: University of Notre Dame Press, 1975.

Shklorskii, Viktor Borisovich. "Art as Technique." Russian Formalist Criticism: Four Essays. Ed. L. Lemon and M. Reis. Lincoln: U of Nebraskat P. 1966. 3-24 "Art as Device." Russian Formalist Criticism: Four Essays. Ed. L. Lemon and M. Reis. Lincoln: U of Nebraska P, 1965.

Taborsky, Edwina. The Textual Society. Toronto. Buffalo, London: University of Toronto Press. 1997.

Todoror, Tzretan. "The Origin of Genres." New Literan' Histom": A Jommal of Theory' and Interpretation. Vol 8. August (1976): 159-170.

Genres in Discourse. Cambridge, New lork. Port Chester, Melbourn. Sydney: Cambridge University Press, 1990.

The Fantastic: A Structural Approach to a Literang Genre. Trans. Richard Howard. Ithaca: Cornell UP. 19-3.

Yolen, Jane, ed. Fatorite Folktales from around the World. New York: Random House, 1986 